\title{
UN TABLADO EN BELÉN Y UNA ESCENA DE TOROS EN PACHAMA. FORMACIÓN DE BUENOS CRISTIANOS Y APROPIACIÓN INDÍGENA DE LA EVANGELIZACIÓN EN LA PINTURA MURAL ANDINA
}

\author{
A BULL TABLADO IN BELÉN AND A TAURINE SCENE IN PACHAMA. \\ FORMING GOOD CHRISTIANS AND INDIGENOUS APPROPIATION \\ OF EVANGELIZATION ON ANDEAN MURAL PAINTING
}

\author{
Olaya Sanfuentes*
}

\begin{abstract}
El siguiente artículo pretende, a partir de una escena costumbrista de pintura mural en la iglesia de Pachama (Altos de Arica), demostrar que, a pesar de su naturaleza secular, esta escena participa del espíritu general del programa iconográfico de esta iglesia surandina. Las paredes de la iglesia están dedicadas a personajes y escenas propias del panteón cristiano, mientras que la escena que me interesa es de naturaleza taurina. Creo que las corridas de toros constituían un espacio festivo conflictivo, ya que algunos representantes del poder secular y otros del eclesiástico lo consideraban un espectáculo cruel y que llevaba a malas prácticas, reñidas con la moral. En esta iglesia que formó parte de la llamada Ruta de la Plata, la escena costumbrista se suma a otras en la búsqueda de la formación de buenos cristianos y en la respuesta indígena específica a esa necesidad. Este fenómeno, en términos temporales, se sitúa en los nuevos impulsos evangelizadores del siglo XVIII y la especial preocupación del Concilio Limense de 1772 por luchar contra los vicios y malas costumbres y la barbarie en particular.
\end{abstract}

Palabras claves: Pintura mural surandina, tauromaquia andina, Altos de Arica, Ruta de la Plata, evangelización.

The following article seeks, departing from a genre scene taken from the mural painting of the church of Pachama, to demonstrate that, despite its secular nature, it shares the general spirit of the iconographic program. The rest of the walls are dedicated to scenes and characters which are typical from Christian iconography, while the scene we are interested in is taurine. We believe that bullfighting was a troubled dimension, since both secular and ecclesiastical authorities thought it was a cruel spectacle which brought people to hotly contested moral practices. In this church, which was part of the so called Silver Route, the genre scene is part of a whole strategy aiming the formation of good Christians. This phenomena can be temporarily placed in the context of eighteenth century missionary efforts, specially the Limense Concilio of 1772, fighting against vices and bad habits.

Key words: Southern Andean mural painting, Andean bullfighting, Altos de Arica, Silver Route, evangelization.

\section{Introducción}

En las paredes de una pequeña iglesia de la precordillera de Arica -los llamados Altos de Aricase pueden apreciar los restos de la pintura mural que adornaba el interior del templo. Es la iglesia del pueblo de Pachama, donde, entre las bellas pinturas que adornan sus paredes, se aprecia una escena pequeña pero que llama poderosamente la atención: un caballero vestido con polainas verdes y levita roja, zapatos negros y sombrero de ala ancha con cinta verde al viento; va montado en un caballo blanco y lidia con un toro en una plaza pública rodeada de edificios. Un perro blanco y manchas negras se abalanza sobre la escena y debajo del caballo hay un personaje verde que pareciera ser un demonio (Figura 1, Figura 1.1). Como esta pintura ha estado siempre en el mismo lugar de la iglesia, constituyendo con el edificio y las otras pinturas de las paredes un todo monumental, se puede decir que estas imágenes, en el orden que fueron concebidas, constituyen una fuente reveladora de la intención de quienes eligieron los temas, los que tienen una especial relación con el lugar en que el templo se erige (Gisbert 1992:17). Los muros evocan sensibilidades locales al tiempo que están insertas en una red de relaciones andinas de todo tipo (Cohen Suárez 2016:4). Lo que se quiere demostrar con este artículo es que, a pesar de formar parte de un muro que presenta escenas costumbristas, esta escena tiene un objetivo moralizante y, por tanto, comulga con el espíritu evangelizador de todo el proyecto iconográfico general y del conjunto monumental en toda su expresión ${ }^{1}$. Y en este cometido, participa

\footnotetext{
* Pontificia Universidad Católica de Chile. Santiago, Chile. Correo electrónico: osanfuentes@ gmail.com
} 


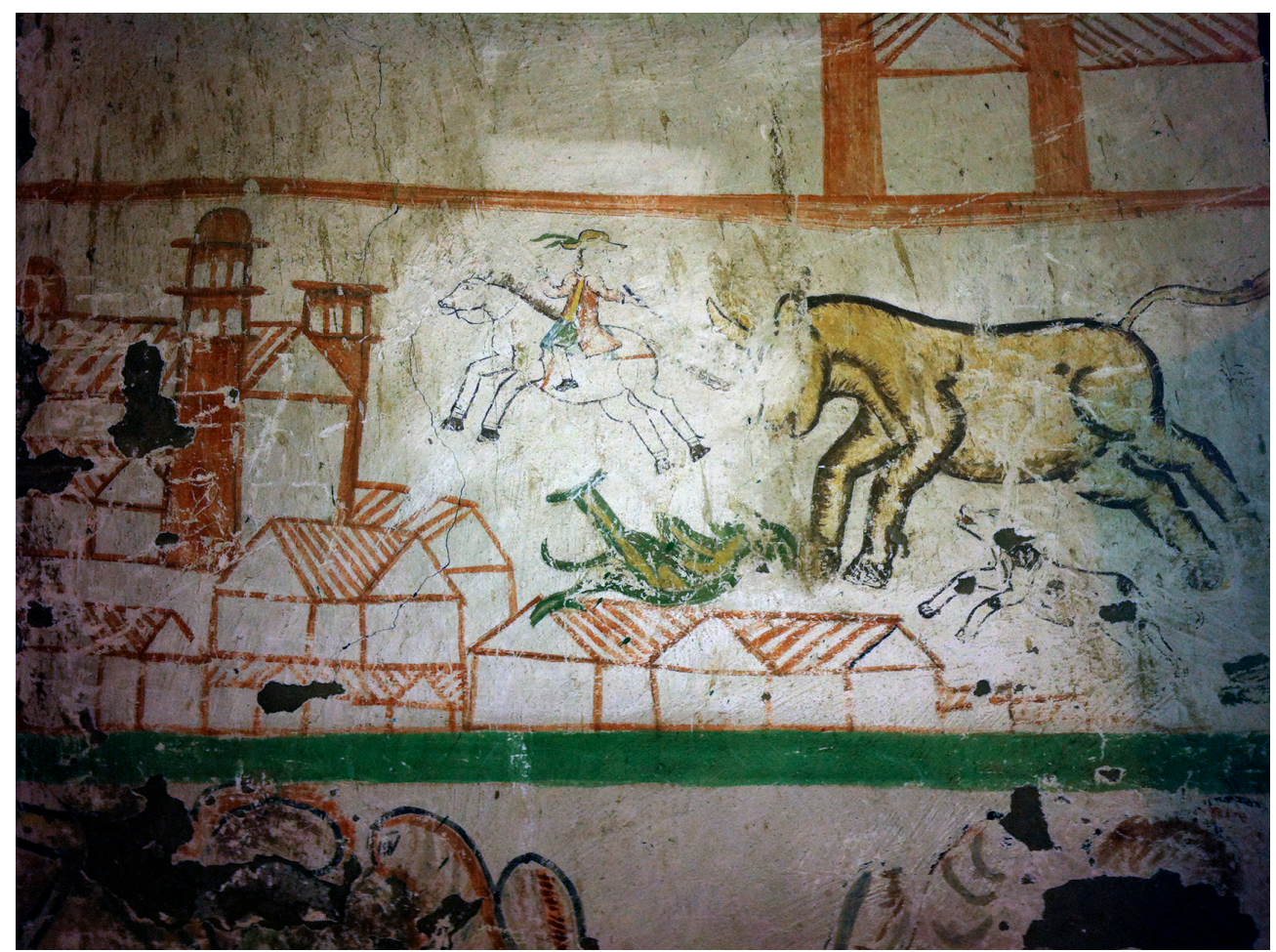

Figura 1. Escena taurina en muro trasero iglesia de Pachama. Fotografía de la autora.

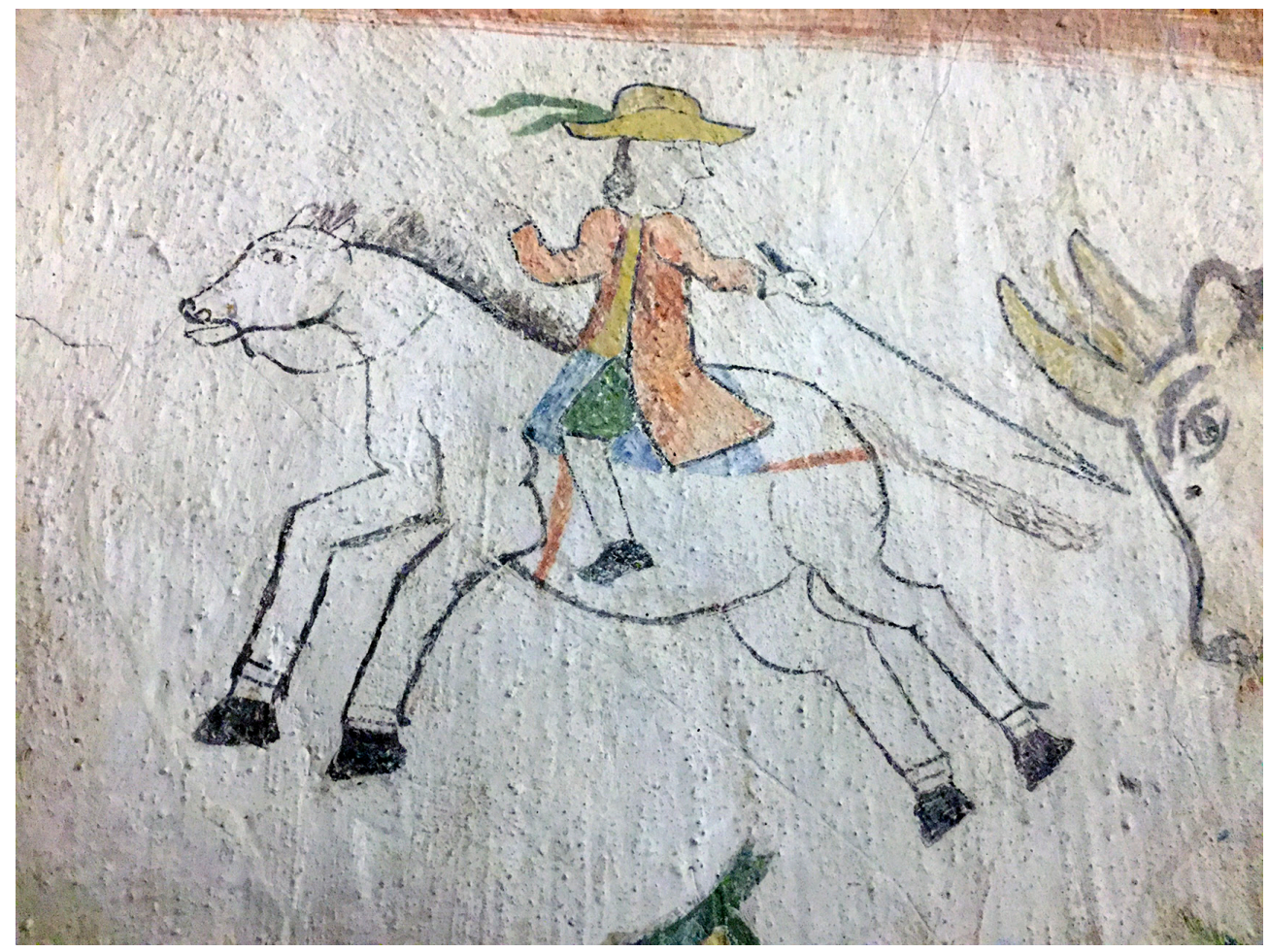

Figura 1.1. Detalle. 
tanto formal como esencialmente en un proyecto general de evangelización. Es la forma que tiene un pequeño pueblo de la precordillera andina de participar del proyecto evangelizador general, desde una posición y perspectiva propias. El indígena, entonces, fue partícipe, desde su condición, de la facturación y apropiación de la evangelización cristiana por medio de la imagen visual.

\section{El pueblo de Pachama en el contexto del siglo XVIII andino}

Pachama es un pequeño pueblo en los llamados Altos de Arica y hoy está habitado por seis personas $^{2}$. Aparece en los documentos coloniales con el nombre de "anexo de san Andrés de Pachama". Era anexo a la doctrina de Belén ${ }^{3}$ y su santo patrón era san Andrés. Tiene un río que pasa cerca del pueblo, el que en períodos coloniales regaba los sembríos y los pastos de este caserío agroganadero. Cerca de Pachama los indios sembraban en comunidad papas, habas, maíz y trigo mudando los sembríos de papas cada año. Para el siglo XVIII, los documentos dicen: "En este anexo hay solo un ayllu de tributarios, que componen el número de 43 entre casados, un viudo y solteros y son los más de ellos forasteros agregados" $"$. El documento del que se cita el trozo que se refiere a Pachama en otras líneas relata que en Belén -cabeza de doctrina-se daban las papas, habas, maíz y trigo y que había alfalfares y fuentes de agua. En Putre -otro pueblo de la doctrina de Belén- se dice que había abundancia y que ahí se producía quinua, cebollas y también había vacas, burras, cabras y ovejas.

No solo los documentos escritos encontrados en los archivos eclesiásticos hablan de la identidad agrícola de Pachama. Las terrazas de cultivo en las laderas de las montañas son vestigios, desde la cultura material, de las labores agrícolas y la fertilidad de antaño. Se sabe también que la arriería era una actividad de los pobladores de esta zona.

En épocas virreinales Pachama formaba parte del llamado camino de la Plata. Esta ruta, que sirvió a los intereses de la Corona para transportar el preciado metal desde Potosí hasta el puerto de Arica, habría utilizado antiguos caminos troperos indígenas para aprovechar la infraestructura y el conocimiento ancestral del territorio. Desde 1574 Arica pasa a ser el puerto oficial de embarque del mineral de plata de Potosí. Sufre una caída de importancia a mediados del siglo XVII por la decadencia de la producción de plata de Potosí; sin embargo, se recupera a mediados del siglo XVIII, observándose una revitalización del mercado colonial circundante a Potosí (Assadourian 1987). Como complemento a estas actividades económicas, la burocracia española y la Iglesia habrían fundado pueblos y establecido doctrinas religiosas para evangelizar a los indígenas. En parte del actual territorio chileno, el camino pasaba por Socoroma, Parinacota y Putre, que aportaban con una infraestructura agrícola y ganadera que la población había desarrollado a partir de épocas prehispánicas. Un ramal del camino se desviaba hacia Pachama y de ahí al pueblo de Belén. De allí la ruta se dirigía a la costa (Guzmán y Pereira 2014:25).

La evangelización era una de las principales funciones de las iglesias de la ruta. Probablemente la urgencia evangelizadora surgiera tras la visita que hiciera Antonio Vázquez de Espinoza en el siglo XVII, denunciando el desamparo espiritual y abandono material que encontró entre estos pueblos ${ }^{5}$. Incluso habla de un pueblo que él tuvo que quemar por haber sido totalmente idólatra (Guzmán y Pereira 2014:17). Se puede también pensar que antes de 1777 Pachama, Belén, Parinacota dependían de la doctrina de Codpa, de donde quedaban bastante lejos como para tener acceso a la asistencia espiritual de los sacerdotes. En estos pequeños asentamientos de difícil acceso y alejados de los principales centros urbanos, la evangelización no había calado en la forma que la Iglesia pretendía. Todavía se conservaban muchas idolatrías o "costumbres perniciosas".

La evangelización pareciera tomar nuevos impulsos durante el siglo XVIII. Incluso hay quienes hablan de una "segunda conquista" (Brading 1998). Todas las iglesias debían contener en su interior un repertorio iconográfico que apoyase esta labor. El Sínodo de Charcas, asimismo, destacaba la importancia de que en las iglesias de las doctrinas se cuidase la dignidad de las imágenes y pinturas, ya que eran "historia y libro" y consideran lo que se ha de imitar y seguir (Luque Alcaide 2001:485).

Ahí donde se necesitaba una evangelización más sostenida y no se podía contar con predicadores permanentes porque el lugar era poco accesible, la imagen visual jugaría un importante rol: formar y consolidar el imaginario. En este contexto es que los doctrineros ${ }^{6}$ encargaban a los indígenas ${ }^{7}$ la facturación de pinturas murales, las que hoy encontramos en los templos de Parinacota, Livílcar, 
Sotoca, Tímar, Pachica y, por supuesto, Pachama. Es probable que la iglesia de san Santiago de Belén también tuviera pintura mural porque en los restos de pared de otro de sus templos -la Candelaria-todavía pueden apreciarse.

El fenómeno debe comprenderse en el marco de la reorientación que experimentaron, en la década de 1770, las estrategias políticas y pastorales que perseguían la homogeneización de las poblaciones indígenas. A esto hay que agregarle la especial preocupación del Concilio Limense de 1772 por luchar contra los vicios y malas costumbres y la barbarie en particular (Castro et al. 2009:29). La zona era heredera de una situación de precariedad endémica, abandono por parte de la autoridad eclesiástica, carencia de sacerdotes encargados de la evangelización y práctica de ritos, por lo que los grupos indígenas habrían caído en la idolatría y vicios generalizados. En este contexto se inserta el programa iconográfico de la Iglesia de Pachama y se puede relacionar tanto formal como materialmente con otra pintura mural de la ruta de la Plata.

Pareciera que las nuevas estrategias surtieron efecto en la zona. Así puede deducirse de una visita del Intendente Antonio Álvarez y Jiménez a fines del siglo XVIII: "Hállase servida la Doctrina en el mejor modo posible, según las secretas indagaciones que se han hecho. Son prontamente auxiliados los enfermos; casi frecuente el Pasto Espiritual; la explicación de la Doctrina dos veces, cuan menos, en la Semana: no se introduce el Cura en las últimas disposiciones de los indios: no les hace condenaciones ni maltrato alguno"(Barriga 1948:115).

A partir de un análisis de pigmentos hecho en las paredes de la iglesia de Parinacota, se ha concluido que las pinturas fueron facturadas a mediados del siglo XVIII (Corti et al. 2014:28). Los autores antes citados se basan, a su vez, en los aportes que hiciera Gabriela Siracusano al estudio de la cultura material en la pintura andina. El azul de Prusia, que figura en la pintura de Parinacota, se habría introducido en el área andina en el último tercio del siglo XVIII, para "suplantar no solo al escasísimo lapislázuli, sino también a los preciados polvos azules" (Siracusano 2008:116). Guzmán y Pereira -y Corti en otro libro de ese mismo tema- agregan que la existencia del blanco de plomo ayuda asimismo a precisar que las pinturas fueron realizadas con anterioridad al siglo XIX, en que este material fue reemplazado por el blanco de zinc, que no es tóxico como el anterior. (Corti et al. 2013:28).
Por las coincidencias materiales con la iglesia de Parinacota y por los trajes de los personajes representados en Pachama, se puede decir que su pintura mural es también del siglo XVIII. Agregaría a esto un dato más cualitativo, cual es la coincidencia en los temas relacionados con la muerte, el pecado y la penitencia en los programas iconográficos de las iglesias andinas del siglo XVIII con pintura mural. En algunos templos hay conjuntos completos que muestran las postrimerías, en otros aparece solamente el Juicio Final y, por último, hay las que junto con otros personajes del panteón cristiano, representan al demonio en escenas costumbristas, como es precisamente el caso de Pachama. Pero todos tienen un carácter admonitorio y advierten acerca de los peligros del pecado y las posibilidades del arrepentimiento. En relación con el arrepentimiento y la penitencia como sacramento religioso, tanto en la iglesia de Parinacota como en la de Pachama hay sendas escenas de un cura confesando a una mujer. La de Parinacota está en mejor estado y por tanto es más fácil de apreciar, pero la de Pachama es muy parecida en su iconografía y composición. En ambas iglesias hay también representaciones del demonio. La iconografía del demonio es medieval y guarda relaciones estilísticas con los demonios que existen en la pintura mural y los lienzos de otras iglesias de la ruta de la Plata. En este sentido, el objetivo catequístico y civilizatorio es indiscutible. Se está luchando no solamente contra las idolatrías, que no habían podido ser extirpadas de raíz, sino también contra las malas costumbres y vicios que se achacan a la población colonial.

Otras fuentes complementarias avalan la aseveración de la naturaleza misional de esta iglesia y las de su alrededor. Desde el ámbito de la cultura material, la presencia de una pila bautismal mencionada en inventarios de 1793 también contribuye a pensar en la actividad misional de esta iglesia (Donoso 2011:292). El bautismo era la práctica que inauguraba la participación de los nuevos cristianos en la iglesia. Los archivos parroquiales de la doctrina de Belén y sus anexos también ayudan a conformar una idea más completa de la actividad evangelizadora. Ahí están registrados en libros de partidas, los bautizos, casamientos y defunciones cristianas. Debían llevarse a cabo según las disposiciones de una Iglesia ya reformada, como demuestra la ordenanza de que los entierros se hagan en cementerios y no en el templo ${ }^{8}$. 


\section{Una ruta de evangelización por medio de la imagen}

La iglesia de San Andrés de Pachama es de arquitectura simple y está compuesta por una nave central y tres capillas laterales. Los muros son de adobe y la techumbre está hecha de un entramado de caña y paja brava. El programa iconográfico de las paredes está conformado por varios santos cristianos y algunas escenas costumbristas. Cuando hablo de programa iconográfico me estoy refiriendo a un sistema creado a priori para representar mediante íconos significativos ciertos elementos que en su conjunto comparten una intención o significación intrínseca. (Panofsky 1985:47). Esto se debe entender en relación con, principalmente, tres fenómenos: las consecuencias de las disposiciones del Concilio de Trento respecto de las imágenes visuales, la posibilidad de inculcar y aceptar a los santos como modelos de virtudes a desarrollar y la opción de elegir aquellos personajes que se relacionen más con la identidad particular del pueblo. Estos dos últimos factores hablan de la relación dialógica entre los productores y los receptores de las imágenes, lo que nos permite argumentar que estas podían significar distintas cosas para diferentes grupos al mismo tiempo (Farriss 2010: 6) o, como aporta Marietta Ortega, que la dialéctica entre lo impuesto y lo apropiado estuvo también mediado por la ritualización (Ortega 2016: 179). También nos permite argumentar, parafraseando a Juan Carlos Estenssoro, que una de las claves del funcionamiento de la pintura mural fue la existencia de una comunidad semántica (Farriss, 2010: 7), un lenguaje -visual en este caso- compartido y aceptado por un grupo heterogéneo en que los que facturan y los que recepcionan la imagen no se diferencian mayormente, sino que se involucran en un acto de participación mutua.

Respecto del primer factor, debemos señalar que el Concilio de Trento fue la reacción católica a las críticas reformistas. Entre las críticas que recibió la Iglesia católica, una significativa fue la veneración excesiva de las imágenes visuales que, a ojos de los protestantes, llegó a convertirse en verdadera idolatría. La contrarreforma católica reaccionó relevando el rol de la imagen visual en los procesos de evangelización, aunque reglamentó y redactó disposiciones especiales para evitar las heterodoxias. En este contexto, la imagen se convirtió no solamente en un arma de lucha frente a la disensión, sino también en el vehículo de la evangelización de sociedades iletradas o de los que hablaban otras lenguas y podían convencerse mediante la inminencia de la visualidad. En el caso de la pintura mural, esta iba acompañada de sermones y ritualidades complementarios para lograr el objetivo principal, que era la compenetración con lo representado, haciendo que la forma acompañara a la función (Gombrich 1999:20). En el caso de la pintura mural que interesa a este artículo, el programa iconográfico estaba en función de adaptar un mensaje admonitorio de los peligros del pecado, a una comunidad andina y rural que participaba de algunos de los vicios de la sociedad colonial del siglo XVIII.

En lo que concierne al protagonismo de los santos en el programa iconográfico en cuestión, hay que decir que las imágenes de los santos hacían posible hacer presente lo que de alguna otra forma parecía invisible. La creencia andina en el animismo de elementos materiales del mundo circundante, facilitaba la ecuación de relacionar ciertos fenómenos de la vida cotidiana con los personajes pintados en las paredes de los templos. Estas imágenes no solo representaban aspectos, sino que estaban ahí, materialmente, disponibles para sus fieles. Cada uno de los santos no estaba ahí en tanto referencia, sino en su misma sacralidad. No solo representando, sino también ejecutando (Díaz et al. 2012: 31). Los santos eran modelos de virtud e intermediarios entre los humanos y la divinidad. Y como adelantábamos líneas más arriba, los santos que se pintaron en el templo son aquellos que más se relacionaban con la identidad rural de Pachama, con el control social y con la premura de advertir frente al peligro del pecado. Este juego se debe, según Okada, a las negociaciones culturales que se efectuaron en relación con las imágenes visuales (Guzmán et al. 2016: 248) y que permitieron la agencia indígena en su apropiación del catolicismo.

Entre los personajes presentes en los muros de adobe están los siguientes: San Cristóbal, un santo y gigante legendario que se caracteriza por ayudar al Niño Jesús a cruzar de un lado al otro del río. Es una figura querida y entrañable y muestra en forma visual las posibilidades de traslados y movimientos espaciales amparados por la divinidad. Representa la asistencia en el camino a caminantes y viajeros y la ayuda a los más débiles, encarnados en el niño. Está también 
el ángel de la guarda, un ser alado que protege a los niños y por eso lo lleva tomado de la mano (Figura 2). También es una iconografía que resalta la asistencia al más vulnerable. En el contexto de la condición jurídica de los indios que son catalogados y tratados como niños a los que hay que proteger, acompañar y educar, esta visualidad podía ser leída por una audiencia mixta y se esperaba

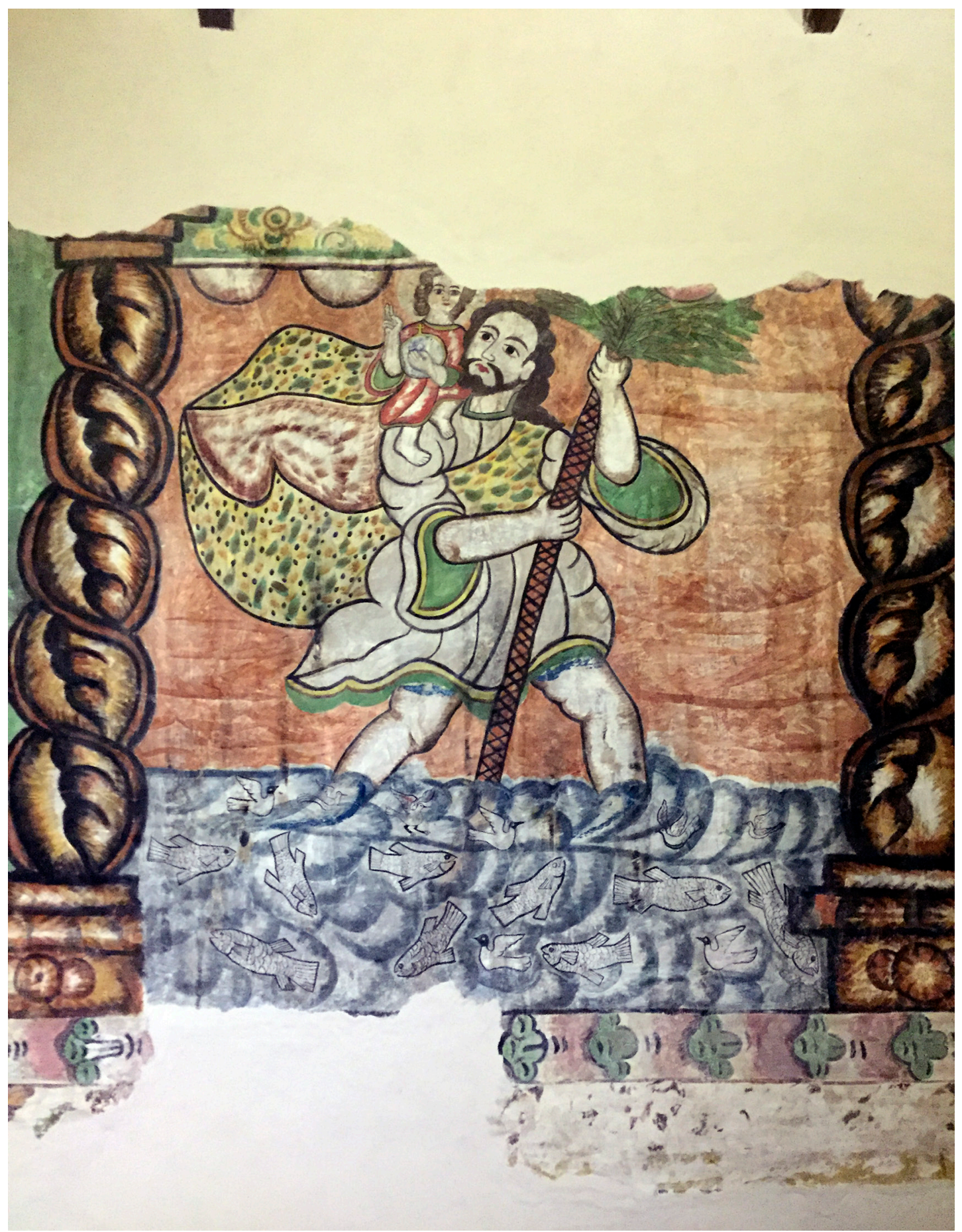

Figura 2. San Cristóbal y el niño. Pintura en los muros laterales de la iglesia de Pachama. Fotografía de la autora. 
fuera reconocible para los indígenas. San Isidro también es fácilmente reconocible y adoptado en el ambiente andino rural, ya que es el santo de los labradores. En una comunidad agrícola como Pachama, este santo era el que específicamente se preocupaba de las condiciones climáticas y de las buenas cosechas. En esta iglesia aparece con varios de sus atributos: una herramienta para labrar, la Biblia y rodeado de un paisaje agrícola cultivado y enmarcado en un par de columnas salomónicas. Está vestido según la moda burguesa del siglo XVIII (Echenique 2007:81) (Figura 3). En este muro también quedan rastros de la representación del legendario san Jorge y el dragón, otro personaje del panteón cristiano que es utilizado para educar en el triunfo del bien sobre el mal, encarnado en el dragón.

El arcángel san Miguel está muy presente en el mundo andino y representa la mediación de estos seres alados, intermediarios entre el mundo de los dioses y el de los humanos. San Miguel es más específico aún, al representar la lucha del bien sobre el mal, el triunfo de la Iglesia sobre el demonio y, por tanto, sobre cualquier idolatría o herejía. En la pintura de Pachama, como en casi toda América virreinal, el arcángel va vestido a la manera romana, portando una espada en una mano y un escudo en la otra. Llaman la atención sus alas multicolores, tan características de las representaciones angélicas del mundo andino. El demonio es representado por un dragón de siete cabezas, monstruo que es mencionado en el libro del Apocalipsis.

Las imágenes del muro interior sur están compuestas por músicos vestidos a la usanza andina y europea. Hay, asimismo, una escena que apenas ha dejado rastro, pero donde podemos reconocer a un sacerdote confesando a una mujer que está hincada a sus pies $^{9}$. La escena taurina hace alusión a vicios específicos de este contexto indígena particular influenciado por Potosí, desde donde llegaban noticias, gentes, objetos y costumbres ${ }^{10}$.

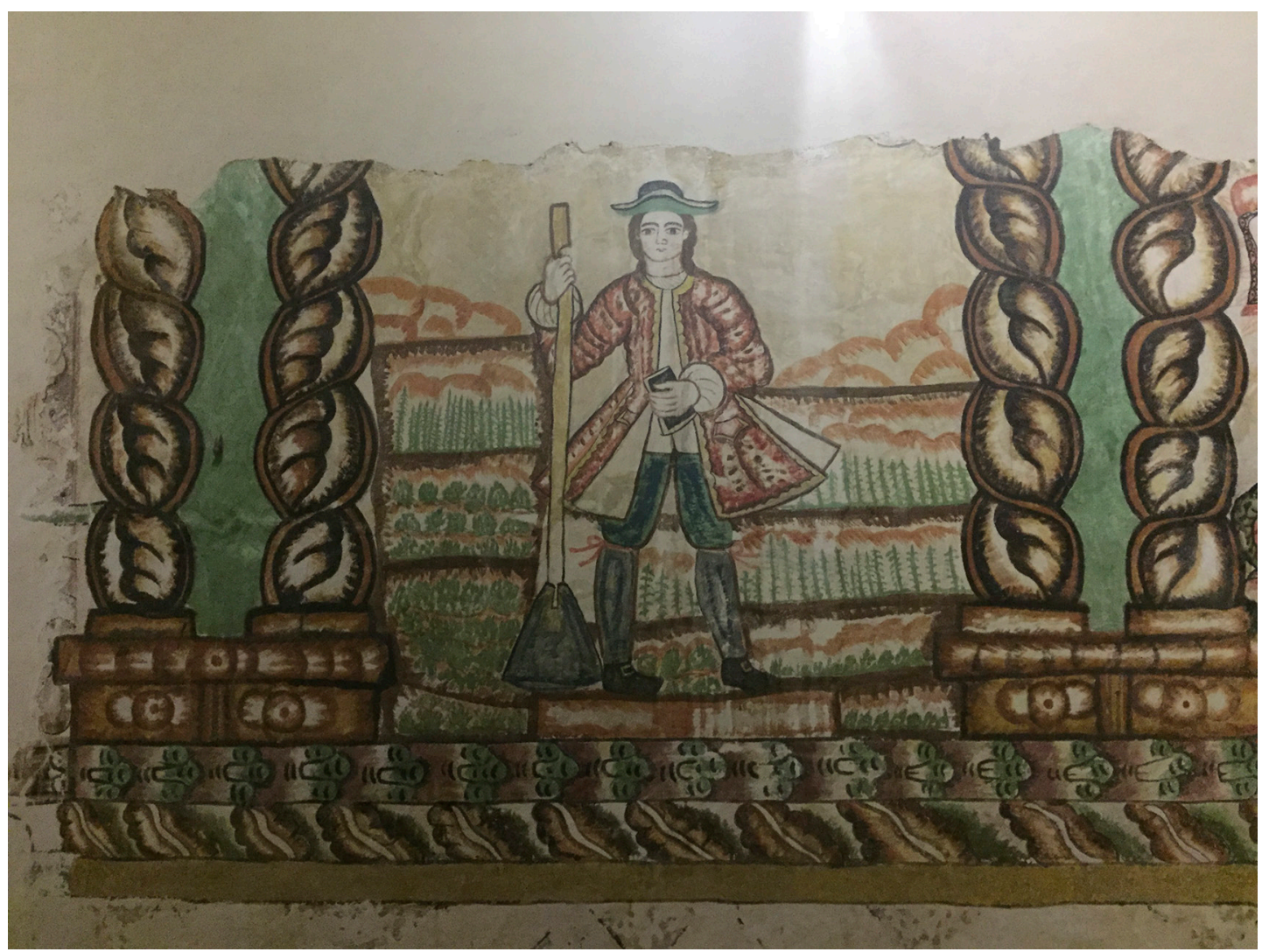

Figura 3. San Isidro Labrador. Pintura en los muros laterales de la iglesia de Pachama. Fotografía de la autora. 
En el muro sur exterior también hay pintura mural: en este caso aparecen los santos Pedro y Andrés (el patrono del pueblo) acompañando, cada uno a un lado, a la virgen María.

Junto con Pachama, otras iglesias del altiplano andino comparten el objetivo de la evangelización por medio de la pintura mural. Los historiadores Fernando Guzmán, Magdalena Pereira y Paola Corti han estudiado en forma exhaustiva este fenómeno para las iglesias de Pachama y Parinacota. Lo novedoso de ese estudio es la convincente relación que los autores establecen entre las imágenes de la pintura mural y los sermones, entre las imágenes y las palabras (Guzmán et al. 2014:124). La interpretación del sentido de las pinturas estaba asistida por los sermones de los sacerdotes y viceversa. También constituye un aporte la sugerencia que hacen de leer el funcionamiento de las imágenes visuales mediante el uso nemotécnico de ellas en la vida cotidiana, de modo de imaginar la reactivación de las ideas de las imágenes y de los sermones en las actividades de la vida diaria (Guzmán et al. 2014:128).

Me gustaría agregar que, junto con las posibilidades nemotécnicas de estas imágenes y la fuerza discursiva de los programas iconográficos elegidos, la dimensión material de todo el complejo debe de haber, asimismo, colaborado en la efectividad de las imágenes visuales. La sensación de permanencia que la pintura mural proyecta en el espectador que entra al templo cada día y ve siempre a los mismos personajes en el mismo lugar, inevitablemente cala hondo en el espectador. Como artefacto estable y permanente que acompaña al individuo y a la comunidad, sus efectos sobre las personas no se explicitan en los documentos pero sí se adivinan eficientes. Estas paredes que contienen imágenes tienen la capacidad de conectar ideas con sentimientos. A esto hay que agregar que las disposiciones eclesiásticas de los sínodos de los siglos XVII y XVIII insistían en la mantención de la decencia de las iglesias y de sus objetos litúrgicos, lo que redundaba en una comunicación y relación más personal e íntima con los personajes y motivos representados en las paredes. En parroquias alejadas como la de Pachama, eran los propios indios los que debían con sus propias manos o reducido peculio colaborar en la mantención de la iglesia. Esto llevaba consigo una suerte de acercamiento emotivo para con los objetos que se esforzaban en mantener. En este acercamiento, cuántas veces tienen que haber mirado con detención a San Cristóbal llevando tiernamente al niño en sus brazos, al arcángel San Miguel destruyendo al demonio o esa escena de toros en que el demonio se aparece en la mitad de la plaza pública.

A estos elementos habría que agregar la familiaridad histórica del mundo andino con la pintura mural, elemento que también explicaría la apropiación y éxito de este tipo de estrategia, así como la disposición andina a leer imágenes visuales tanto realistas como abstractas (Figura 4). Esta competencia proporcionaría herramientas para familiarizarse con ciertas estilizaciones pictóricas presentes en las murallas de esta iglesia como en todas las de la zona que nos interesa. En el caso de Pachama, el espacio construido queda enteramente pintado. Entre una imagen y otra, hay diversos patrones coloreados de figuras geométricas, flores, puntos, líneas, grecas y columnas que dan una sensación total de continuidad y que constituyen el fondo pictórico sagrado de las escenas de los santos. Los personajes sagrados elegidos parecieran estar habitando un paraíso que cobija al feligrés que vive diariamente las dificultades del altiplano o la precordillera, pero que puede entrar al templo cuantas veces quiera para verse inmerso en este espacio sacralizado.

"Las civilizaciones prehispánicas de Mesoamérica y los Andes centrales tuvieron en la pintura adherida a los muros del edificio, una de sus formas de expresión artística más difundida" (Flores Ochoa et al. 1991:167). Efectivamente, esta práctica artística tiene hondas raíces en la cultura andina precolombina. En el área andina, la cultura inca desarrolló una pintura mural de figuras geométricas que se asemejan mucho a los motivos textiles tokapus ${ }^{11}$ de los unkus. Estas figuras, que eran utilizadas por la nobleza y la monarquía inca, aluden a un cuerpo sagrado que, al cambiar de soporte en las paredes de las iglesias, conservan su sacralidad simbólica. De igual forma, tanto en épocas coloniales como en las prehispánicas, la pintura mural y los textiles, respectivamente, ayudaron en la difusión de las visiones de mundo, ideologías y estética de las sociedades hegemónicas.

La pintura mural tiene asimismo relación con otro tipo de soporte material que fue pintado y que tenía connotaciones sagradas: los keros $^{12}$. Al igual que la pintura mural, estos objetos debían comunicar intenciones y conocimiento mediante la iconografía y el color, con el objetivo de formar y consolidar el pensamiento de las nuevas sociedades. Por otra 


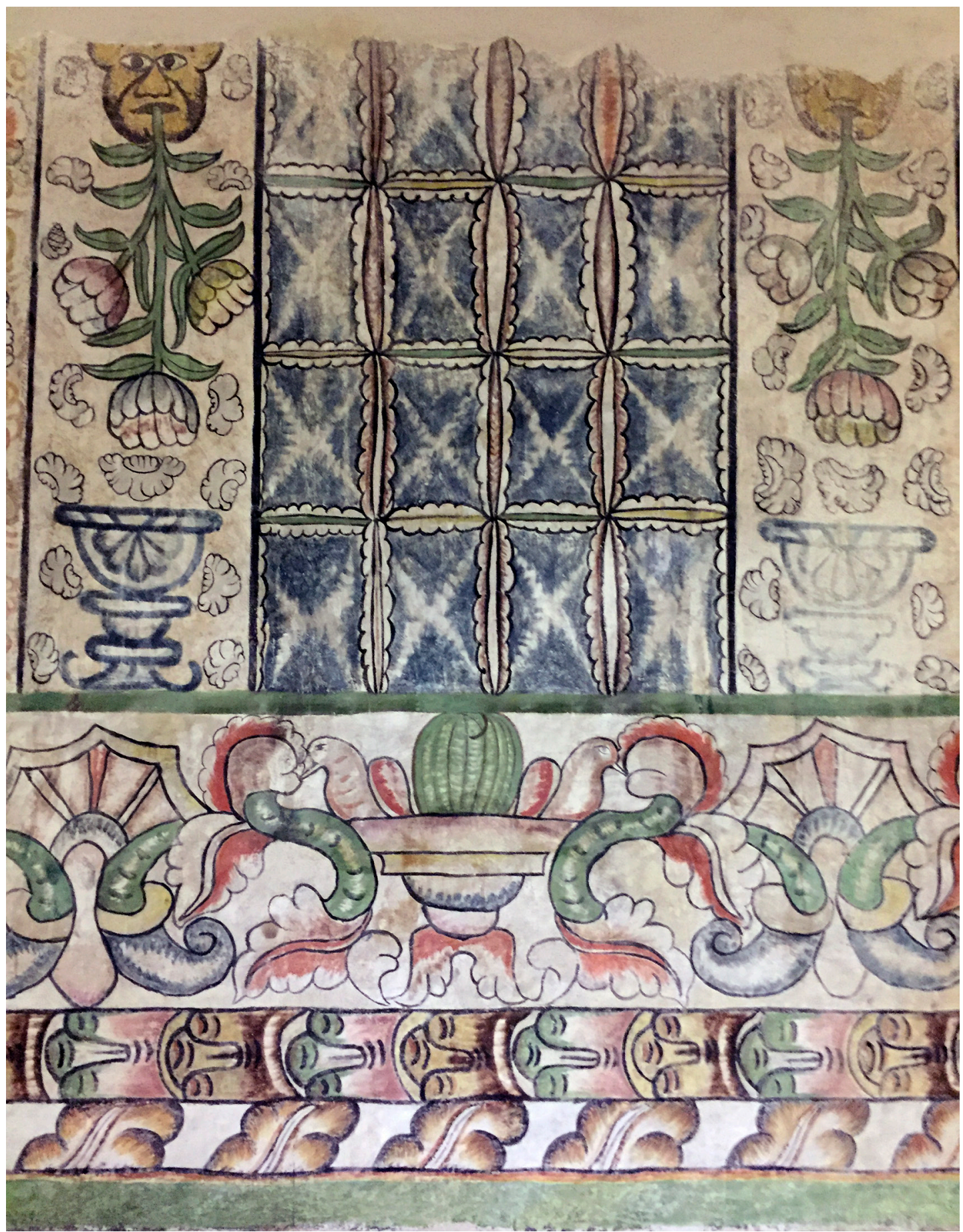

Figura 4. Detalle de la pintura en los muros laterales de la iglesia de Pachama. Fotografía de la autora.

parte, los keros, al igual que las paredes del nuevo virreinato, debieron acomodarse a la conquista visual que trajo consigo el español. Junto con los pictogramas tradicionales, los vasos ceremoniales andinos adoptaron figuras tomadas del imaginario europeo clásico y renacentista.

Podemos decir, entonces, que había en los Andes una cultura visual que se manifestaba en diferentes 
soportes materiales y que dotaba de familiaridad y pertenencia a quienes convivían con ella.

\section{Escena del toro}

En el área centro sur andina del continente sudamericano existen varias iglesias con una pintura mural que comparte contexto histórico cultural, estilo, espíritu evangelizador e iconografía. Junto con santos, vírgenes y episodios de la vida, Cristo, hay siempre animales incluidos en las paredes de estas iglesias. $\mathrm{Y}$ el toro es uno de esos animales que generalmente aparece en términos simbólicos. En Pachama, en cambio, el toro está representando una escena de vida festiva virreinal, frente a ella la iglesia tiene muchas aprensiones y quiere combatir en la formación de buenos cristianos.

El toro está presente en el imaginario andino porque la crianza del ganado vacuno en los Andes centrales comenzó casi inmediatamente después que los españoles conquistaron a los incas (Tomoeda 2013:205). Según Manuel Castillo Martos habrían discrepancias acerca de la fecha exacta en que atracó el primer bajel con toros bravos. Sería el mismo rey Fernando el que habría dispuesto que esos primeros toros no fueran sacrificados hasta que aseguraran su descendencia.

El toro, como dijimos líneas más arriba, está presente en las manifestaciones visuales andinas. A siete horas de La Paz está la conocida como Casa de Bonifacio Riveros que es una casa abandonada que data de comienzos del siglo XIX. Hay ahí, entre otras representaciones de pintura mural, una escena de rutinas locales con esclavos negros pisoteando la uva. Los acompaña un toro. En la iglesia de Callapa el arcángel San Miguel está colocado entre el toro -que simboliza la ira- y el cordero, que es símbolo de mansedumbre. En la iglesia de Curahuara de Carangas se puede apreciar una pareja de bovinos en el contexto de la representación de los animales que entran al arca de Noé para El Diluvio Universal, escena que está pintada en el baptisterio del templo. Estas son apariciones del toro en contextos de la ruta de la Plata; pero sabemos que en el área cuzqueña el toro está, asimismo, en varias paredes de templos religiosos.

Por otra parte, las corridas de toros comenzaron apenas los españoles se hubieron establecido en el nuevo territorio. La primera corrida en suelo peruano habría sido en Lima el 2 de marzo de 1540, para celebrar el bautizo de Atahualpa, el último soberano inca. Otros autores, en cambio, hablan de 1538 (Molinié 2013). Las corridas habrían seguido realizándose durante todo el período virreinal. Hasta la construcción de la Plaza de Acho, la corrida de toros se organizaba en la Plaza de Armas cuatro veces al año para celebraciones como Epifanía, San Juan, Santiago y la Asunción. Además de las corridas eventuales organizadas a la llegada del nuevo virrey u obispos hacia fines del siglo XVIII las corridas de toros se habían difundido también entre los indígenas.

Volviendo a nuestra escena de interés, creemos que el personaje que está debajo del toro es un demonio, ya que, a pesar de que se nota poco en la pintura, su parecido con otros muchos demonios en la pintura andina es indiscutible. Y no solo en la pintura andina, sino también en los dibujos de Guamán Poma de Ayala y en otras ilustraciones de crónicas americanas que circularon por el virreinato del Perú durante el período colonial.

Los doctrineros de indios habían familiarizado a sus feligreses con las figuras visuales que representaban los infiernos, la muerte, el pecado y el demonio. El imaginario visual de estas imágenes provenía de grabados europeos en estampas sueltas, libros de devoción y catecismos ${ }^{13}$. Estos contenían imágenes que los indígenas americanos copiaban, adaptaban y combinaban. Los grabados se convirtieron en valiosos instrumentos de propaganda de la fe católica, razón por la que su producción a gran escala fue un requerimiento fundamental por parte de la Iglesia (Esponda de la Campa y HernándezYing 2014:11).

Esto explica las grandes series monumentales pertinentes a estos temas admonitorios en algunas iglesias del altiplano y la presencia puntual del demonio en otras escenas como la de la corrida de toros en Pachama.

\section{Toros en Potosí}

Como eslabón de un circuito que tenía su propia lógica, tanto comercial como evangelizadora, es que debemos pensar la existencia de esta escena. Los problemas aparejados a la ciudad de Potosí ${ }^{14}$ son compartidos por otras localidades más pequeñas que conforman la ruta de la Plata, o bien son representativos de vicios y problemas más generales que se necesita erradicar tanto para el buen funcionamiento del Imperio y su burocracia 
como para la formación de buenos cristianos. Entonces, si un viajero venía de Potosí y hacía escala en Pachama, se encontraba con la postura de la Iglesia frente a las corridas de toros, pintada en la iglesia del pueblo.

Si leemos la crónica de Arzans y Ursúa ${ }^{15}$ y nos detenemos en su descripción del siglo XVIII que le toca vivir, no podemos sino reparar en la cantidad de desórdenes y hechos de violencia que describe para la ciudad de Potosí. La violencia tiñe la vida diaria, así como también la excepcionalidad festiva, convirtiéndose probablemente en una de las principales preocupaciones tanto de la autoridad civil como de la eclesiástica. El cronista relata: "Las desgracias y muertes siempre continuadas en esta Villa, tan memorable por esto como por la riqueza de su cerro" (Arzans y García Pabón 2000:275).

En este contexto, las lidias de toros, a pesar de ser incuestionables en cuanto a su necesidad en el espacio festivo y como arte de una tradición hispánica y monárquica, no hacían sino colaborar al ambiente de violencia generalizado. Y para muchos, eran costumbres bárbaras que impedían el vivir políticamente y colaboraban en la convivencia con el demonio.

Las primeras noticias de corridas de toros en la ciudad de Potosí datan de 1555. Al establecerse al apóstol Santiago como patrono de la ciudad, no sería raro que las primeras corridas hayan sido a propósito de su fiesta, el 25 de julio. Así era la costumbre en cada ciudad del imperio español donde Santiago era el patrono. De hecho, cada noticia del cabildo secular que describe las fiestas del apóstol, las pinta con la presencia de los infaltables toros y el paseo del estandarte real. En general se lanzaban cuatro toros, que eran traídos del campo por los indios, a quienes había que pagar doscientos pesos. Muchas veces, a las corridas les seguían juegos de garrocha y sortijas. Se corrían en la plaza pública y para ello los mayordomos se preocupaban que hubiera barreras para que los animales no se desbandaran hacia la ciudad y tablados para sentar a los personajes más ilustres. El pueblo, en cambio, permanecía de pie o se acomodaba en las gradas que a veces se construían. También se subían a los tejados de las casas vecinas (Castillo Martos 2013:211).

Las corridas se llevaban a cabo en la plaza del Regocijo o Plaza Mayor. Fue construida por el virrey Toledo y en 1636 se redujo a la mitad respecto de su tamaño original (250 varas de largo y 130 de ancho). Esta plaza respondía al tipo clásico de las plazas renacentistas españolas, con portales y una grandiosa escala para subir a la sala del ayuntamiento. Además de ser centro cívico, las plazas españolas y americanas se habilitaban también para espectáculos (Arzans y García Pabón 2000:451).

La práctica normal del siglo XVIII era que negros e indios jineteaban a pelo arriba de los toros. Luego los nobles los rejoneaban y alanceaban a caballo. Las autoridades se ubicaban en los balcones, en sitios reglamentados según el rango. Las corridas eran costeadas por los nobles de la sociedad virreinal, personas de alto rango, o bien, por las instituciones civiles. Antes de las corridas, las fiestas contemplaban el paseo de carros alegóricos $\mathrm{y}$ juegos florales.

Corridas de toro había siempre para carnaval. Las llamadas carnestolendas llevaban siempre aparejados los famosos regocijos, entre los que los toros eran muy populares. Eran fiestas muy esperadas, porque las costeaban los adinerados, y repartían mates del Paraguay, mistelas y colaciones (Arzans y García Pabón 2000:244). Aquí ya había semilla para eventuales vicios y excesos, porque la regla era que las fiestas terminaran con muchos borrachos, enfermos y accidentados por riñas. Todo esto era visto como la intervención del mismo demonio (Arzans y García Pabón 2000:244).

Las corridas de toros tenían mal término: en 1727 esas fiestas dejaron como saldo 18 personas muertas, además de caballos y mulas útiles. "Uno de aquellos feroces brutos arremetiendo a su caballo lo ensartó en una de sus puntas y lo llevó asido gran trecho de la plaza con mucho riesgo de su persona" (Arzans y García Pabón 2000:244). En 1735 es descrito como una verdadera calamidad por las víctimas de las corridas de toro de carnestoldas. Trece fueron los muertos esa vez (Arzans y García Pabón 2000:385).

También había problemas de riñas entre personas en los eventos de toros, cuando las autoridades se disputaban los lugares a ocupar en los tablados públicos construidos especialmente para la ocasión. Se desairaban unos a otros y se amenazaban con no permitir ni costear los toros. Esto era algo impensable porque era el regocijo más esperado de la Villa de Potosí (Arzans y García Pabón 2000:367).

No solo la violencia se develaba en estas fiestas. Las mujeres, a ojos de los más conservadores, se arreglaban en demasía, mostrando su vanidad e incitando a los hombres a que las miraran con lujuria. 
Se temía de que entonces se pasara a la cercanía no deseada de los cuerpos. A propósito de esto es que se hablaba y discutía mucho de la decencia y el decoro, virtudes que desde el Concilio de Trento se intentaba inculcar entre los fieles. También se incurría en muchos gastos innecesarios para algunos. Las borracheras en los días de corridas de toros eran también vicios deplorados por la autoridad y un pecado para la Iglesia.

Otros eventos que se celebraban con igual fastuosidad que en la metrópoli eran las entradas de obispos y arzobispos a las ciudades. Famosa fue la entrada del arzobispo Borja a la ciudad de Charcas, cercana a Potosí. Para la entrada de Borja, se rajonearon 12 toros en seis días consecutivos, una cifra muy grande si se compara con las fiestas homólogas limeñas, donde generalmente se dedicaban uno o dos días a los toros cuando entraba un arzobispo (Latasa 2012:190). Todo indica que en el altiplano andino había una gran afición a los toros y que la Iglesia americana las miraba con recelo.

En un contexto más amplio de la Iglesia católica universal, existe una larga trayectoria de tensiones entre el papado y la monarquía española respecto de los toros, conflicto que se manifestó asimismo en sus colonias americanas. El origen de la postura eclesiástica al respecto la encontramos en san Agustín, quien condena no solo las "agitaciones" taurinas sino todos los espectáculos masivos paganos, que caracteriza como de impiedad esencial. Las considera invenciones demoníacas contra la divinidad misma, engaño para llevar a conductas socialmente disolventes y éticamente pervertidoras (Castillo Martos 2013:143). La teoría de los espectáculos paganos como una invención demoníaca se extiende por muchos capítulos en La Ciudad de Dios.

La piedad, que se había definido como una renuncia expresa a la satisfacción sensorial, se propone como heroica cuando se ejercita negando espectáculos como el taurino. Desde entonces, aparecerían en el mundo cristiano varios tratados de moral que enfrentarían el problema del espectáculo público en general y el de los toros en particular. Había preocupación no solamente por las almas de los feligreses, sino por los mismos clérigos que incurrían en pecado mortal y eran candidatos a excomunión si veían lidiar toros.

Las corridas de toros constituían un espacio visible que escondía tras de sí las tensiones respecto del orden social urbano en la ciudad, así como de la moralidad cristiana en las colonias de la monarquía católica española. Al pesquisar las noticias referidas a este evento, podemos ver cómo se involucraban los principales poderes de la época -el eclesial y el secular- en discusiones que tenían como trasfondo las oportunidades y obstáculos para formar buenos cristianos y buenos ciudadanos, respectivamente. El que fuera este un espacio de tensión, no significaba que estos dos agentes hayan estado siempre enfrentados, sino más bien que las corridas de toros eran una excusa para proponer una determinada forma de gobernar las almas y las mentes de los súbditos. En las fiestas se jugaban valores como la austeridad, la piedad, la moralidad y el orden que, en el escenario lúdico y necesario de la fiesta, no siempre encontraban un campo de cultivo fértil para poder desarrollarse. En las corridas de toros ocurrían muchas cosas que atemorizaban y escandalizaban a ciertos eclesiásticos o autoridades porque el pueblo podía desbandarse. En este sentido, entonces, las fiestas en general y las de toros en particular, ejercieron un importante papel en la vida urbana de los habitantes de Potosí hasta comienzos del siglo XIX.

No es raro que esta entretención haya tenido sus controversias en territorio americano. Ya en 1567 el papa Pío V la había prohibido para la cristiandad bajo pena de excomunión. Imbuido del espíritu contrarreformista romano de mediados del siglo XVI, el Papa decidió luchar contra todos los vicios e inmoralidades y auspiciar una vida terrenal cristiana austera y virtuosa. Dentro de las costumbres que detestaba por considerarla pagana y bárbara estaba la fiesta de los toros. Mediante una bula prohibió los toros con castigo de excomunión inmediata y perpetua a quienes desobedecieran y a los que murieran lidiando se les negaría sepultura cristiana (Pereira Salas 1947:65). En Italia la prohibición fue acatada de forma inmediata, no así en países como España, Francia y Portugal donde la tradición de los toros estaba muy arraigada. Era el espectáculo público más popular de España. El rey interpretó la bula a su manera, argumentando que la forma en que las corridas se llevaban a cabo en su territorio no era peligrosa, que era una forma en que sus vasallos se entretenían y que, además, constituían un ensayo de los ejercicios militares (Villarroel 1783:351).

En España la bula no se hizo nunca pública. Incluso Felipe II intentó convencer al Papa de que la derogase, pero no tuvo éxito. Esperó la llegada del nuevo Pontífice-Gregorio XIII- para renovar las conversaciones. 
Las instituciones eclesiásticas americanas mostraron especial preocupación por aquellas fiestas en que la población tendía al desbande. Las corridas de toros constituían en este sentido una instancia potencialmente peligrosa. Por eso es que los Concilios, durante todo el período colonial, se detienen en esta instancia. Para el siglo XVIII, el Concilio Limense de 1772 prohíbe las corridas de toros en los días de fiesta y en los días anteriores a ellas, en que suelen hacerse unas corridas nocturnas llamadas "Iluminados". Cuando esto ocurre, se llega a la "disolución y desorden", dicen las disposiciones (Vargas Ugarte 1952:64). Especial prohibición tienen los clérigos de asistir al espectáculo taurino, para que así puedan dar buen ejemplo a sus feligreses (Vargas Ugarte 1952:70).

El caso es que en cada colonia del imperio español en América se pueden apreciar las disputas entre sendos poderes por el tema de las corridas de toros. Hay que agregar, no obstante, que hacia el siglo XVIII las fiestas en general se habían convertido en un espacio donde ocurrían todo tipo de desmanes que eran mirados con recelo por las autoridades. Las menciones a bailes, danzas, cantos, comidas -todo en exceso-comenzaron a proliferar tanto en escritos como en imágenes, "instalando este antiguo topos en clave andina" (Siracusano 2010:100).

\section{Los toros en la pintura mural andina}

Hay que entender la representación y denuncia de las corridas de toros en la pintura mural andina en su espacio geográfico temporal y cultural más específico. Si bien este rincón del imperio compartía tanto las formas de entretención y ritos del resto de la colonias, así como las preocupaciones eclesiásticas y seculares frente a los desbandes, habían aquí ciertas particularidades culturales que hacían de la fiesta de los toros un espectáculo de características propias. Según Manuel Castillo Martos, esta ceremonia se relaciona de alguna forma con las batallas rituales andinas, tinkuy (Castillo Martos 2003:213): hombres que luchaban entre sí desde la época prehispánica. Había características comunes, ya que en ambas prácticas se daban la ejecución y el sacrificio. Al amparo de esta tesis, podemos entender, entonces, que la violencia aparejada a las corridas de toros era parecida a la que se ejercía en prácticas rituales andinas legendarias. Desde el punto de vista de la sociedad colonial, se creía que era el demonio el que actuaba en las prácticas religiosas ancestrales que no se habían podido erradicar de raíz o que pervivían en ceremonias sincréticas que fueron registradas como idolatrías.

Otra interpretación que se ha dado al éxito de la presencia del toro en el altiplano es la que lo relaciona con la virilidad y fertilidad. En ceremonias de iniciación del área potosina hasta hoy los adolescentes son expuestos a varias pruebas en que se supone deben comportarse "como toritos". En otras ceremonias de libaciones del área de la actual Bolivia, los vasos ceremoniales llevan esculpidos unos toros.

A partir de la misión evangelizadora de la pintura mural entendemos la presencia literal del demonio en la pintura de la iglesia de Pachama. La Iglesia lucha contra la barbarie y las malas costumbres y ve en la violencia y los excesos la presencia del mismo demonio entre los habitantes de las ciudades. Ya el padre Ocaña había escrito un verso en que describía cómo el demonio se aparecía en una plaza de Potosí y peleaba su protagonismo contra la virgen.

Belén y Pachama son pueblos pequeños, por lo que cuesta imaginarse que la lidia del toro representada en las murallas pudo haberse dado ahí. Sin embargo y a pesar de su tamaño, sabemos que en 1845 hubo corridas de toros en la plazoleta de Belén. Tenemos esta noticia porque se acusa al mayordomo del Santísimo de usar la tela con que se tapa el santísimo, para adornar el tablado que se usaría para la corrida ${ }^{16}$. El acusado se defiende diciendo que no fue el paño del santísimo, sino uno muy viejo el que habría utilizado y que como no tenía intención de profanar cosas sagradas, lo quitó apenas se le advirtió ${ }^{17}$. Tanto Belén como Pachama celebraban cada 25 de julio al apóstol Santiago, ya que era el patrono de la doctrina de Belén, del que dependía el anexo de Pachama. No hay razón para pensar que no se corrían toros en estos pueblos si así ocurría en cada ciudad y villa donde el santo apóstol era el patrono. Y no solamente para celebrar al patrono es que se corrían toros. Para la canonización de un santo, para otras fiestas patronales, para celebrar una victoria militar o el nacimiento de un nuevo miembro de la familia real, se corrían toros en cada rincón del imperio.

La afición a los festejos taurinos debió ir en aumento a lo largo del siglo XVIII y no sufrió manifiestamente la actitud antitaurina del mundo ilustrado. Incluso aumentaron las corridas (Castillo Martos 2013:136). 


\section{Reflexiones finales}

Mediante este artículo hemos querido demostrar que una escena pequeña y a primera vista marginal dentro del contexto de un programa iconográfico de pintura mural, forma parte de un sistema más amplio de visualidades complejas, de preocupaciones pastorales y de intenciones de evangelización general. Cuando digo visualidades complejas me refiero a los mecanismos, agentes y productos que son capaces de recibir influencias visuales de diferentes soportes y tradiciones para articularlos en un sistema nuevo. La escena en cuestión es una pieza más de un programa iconográfico que, más que promover unas ciertas devociones, se ha adaptado a la identidad y los eventos de una localidad donde se considera necesario "la supresión de prácticas inadecuadas, a la vez que para reforzar la fidelidad de la población a la Iglesia y a la Corona" (Guzmán 2016: 257).

La escena pertenece a un conjunto que es capaz de recoger tradiciones ancestrales de decorado de paredes con un significado sagrado simbólico. $\mathrm{Al}$ emular, entre otras visualidades, las figuras geométricas relacionadas con la vestimenta de la figura del Inka y las estilizaciones de los vasos sagrados, esta parte del programa iconográfico también puede ser leída en su dimensión sacra. Otros iconos provienen de la influencia del cristianismo y su panteón de personajes y visualidades que son elegidos de acuerdo con las necesidades del lugar. Visualmente, esas imágenes han llegado al virreinato por medio de grabados y pinturas, telas y objetos litúrgicos y sus mensajes se refuerzan con libros religiosos y los sermones de los doctrineros.
Transferencias espaciales y temporales se instalan, entonces, en esas paredes que inundan la vista en el diario vivir tanto como en el momento ritual. A esta transferencia de carácter mixto (espacialtemporal), Cohen Suárez la denomina movilidad estática (Cohen Suárez 2016:13), porque desde la estabilidad de la pared es capaz de informar de los movimientos temporales y espaciales. Quiero agregar que estas paredes son capaces de encarnar la conectividad de mundos atlánticos y andinos en un pequeño y remoto lugar de la precordillera andina, alcanzando una resonancia local (Cohen Suárez 2016:13). La pequeña dimensión del pueblo estudiado y su lugar periférico respecto de las tomas de decisiones no fueron un obstáculo para que Pachama fuera partícipe de los problemas y preocupaciones de las autoridades civiles y eclesiásticas del imperio español del siglo XVIII. Al contrario, desde este rincón de la precordillera de Arica, la comunidad indígena participó de los objetivos de la evangelización del siglo XVIII, de la ruta comercial y de las influencias del virreinato, de las actividades lúdicas de las grandes ciudades y lo hizo de una forma andina, incorporando todo lo que el sistema colonial le imponía en un sustrato por ellos conocido y que dotaba de sentido.

\section{Agradecimientos}

Financiado por proyecto Fondecyt 1141032 y FONDAP N 15110006 (Centro Interdisciplinario de Estudios Interculturales e Indígenas). Agradezco la lectura erudita y minuciosa de Rafael Gaune, la edición y corrección de Irene Correa. Agradezco a los eventuales evaluadores de este texto.

\section{Referencias Citadas}

Archivo Arzobispal de Arequipa. Sección Vicaría, Serie Arica, Subserie Belén. N 66, Mayordía de las Cofradías de Belén. 21/01/1845-09/07/1846. “1845: Sobre que Francisco Cuellas sea Mayordomo de las Cofradías de Belén en lugar de Blas Benavides". Sin Foliar).

Archivo Arzobispal de Arequipa. Serie: Arica. Subserie: Belén. Demarcación y lista de contribuyentes de diezmos. 10/07/1787 Foja 2r.

Archivo Nacional. Fondo Parroquial de Belén, Vol. 5. Microficha 7.

Arzans de Orsúa y Vela, B. y García Pabón, L. (ed.)

2000 Relatos de la Villa Imperial de Potosí. Plural Editores, La Paz.
Assadourian, C.

1987 "Los señores étnicos y los corregidores de indios en la conformación del Estado Colonial". Anuario de Estudios Americanos, 44:325-426.

Barriga, V.

1948 Memorias para la Historia de Arequipa. Tomo IV, La Colmena S. A., Arequipa.

Brading, D. A.

1998 Orbe indiano: De la monarquía católica a la república criolla, 1492-1867. Fondo de Cultura Económica, México.

Castillo Martos, M

2013 Toros en el altiplano andino (1550-1560). Una aproximación a su historia. En Fiesta de toros y sociedad: 
actas del Congreso Internacional celebrado en Sevilla del 26 de noviembre al 1 de diciembre de 2001, editado por A. García-Baquero y P. Romero de Solís, pp. 211-227. Universidad de Sevilla-Fundación Real Maestranza de Caballaría, Sevilla.

Castro, N., Chacama J. y Mir, R.

2009 "Excitar y subyugar. Pastoral de la imagen y poblaciones indígenas en Arica Colonial”. Diálogo Andino, 34:57-80.

Cohen Suárez, A.

2016 Heaven, Hell, and Everything in Between: Murals of the Colonial Andes. University of Texas Press, Austin.

Corti, P., Guzmán, F. y Pereira, M.

2013 La Pintura Mural de Parinacota, en el último bofedal de la ruta de la plata: Arica. Fundación Altiplano-Universidad Adolfo Ibáñez, Santiago.

Corti, P., Guzmán, F. y Pereira, M.

2014 "Imagen y palabra en la evangelización y catequesis de la Ruta de la Plata. Potosi-Arica". Hispania Sacra, 66:119-168.

Díaz Araya, Alberto, Luis Galdames y Wilson Muñoz

2014 "Santos Patronos en Los Andes. Imagen, símbolo y ritual en las fiestas religiosas del mundo andino colonial (siglos XVI-XVII)". Alpha 2014, pp. 23-39.

Donoso, M. (coord.)

2011 Iglesias de la Antigua Ruta de la Plata. Corporación Patrimonio Cultural de Chile, Santiago.

Donoso, $\mathrm{M}$.

2011 Iglesias del Desierto, Editorial Ograma, Santiago de Chile.

Echenique, E.

2007 Iglesia de Pachama: estudio, diagnóstico y propuesta de intervención para el rescate de sus pinturas murales. Tesis para optar al grado de Licenciado en Arte, Mención en Restauración, Pontificia Universidad Católica de Chile, Santiago.

Esponda de la Campa, C. y Hernández-Ying, O.

2014 "El Arcángel San Miguel de Martín de Vos como fuente visual en la pintura de los reinos de la monarquía hispana". ATRIO, 20:8-23.

Farriss, Nancy.

2010 "Introductory Essay. The Power of Images". Colonial Latin American Review, Vol. 19, № 1, pp. 5-28.

Flores Ochoa, J., Kuon Arce, E. y Samanez, R.

1991 "De la evangelización al incanismo. La pintura mural del sur andino". Histórica, 15:165-203.

García-Baquero A. y Romero de Solís, P.

2003 Fiesta de Toros y Sociedad: Actas del Congreso Internacional celebrado en Sevilla del 26 de noviembre al 1 de diciembre de 2001. Fundación Estudios Taurinos y Universidad de Sevilla, Sevilla.

Gisbert, T.

1992 "La pintura mural andina". En Colonial Latin American Review, Vol. 1, No 1-2, pp. 109-145.

Gisbert, T.

1998 Pintura Mural en el área Centro Sur Andina. Ministerio de Educación, Cultura y Deporte-Organización de los Estados Americanos, La Paz.

Gombrich, E.H.

1999 Los usos de las imágenes. Estudios sobre la función social del arte y la comunicación visual. Fondo de Cultura Económica, México.
Guzmán, F., Meir, M., Pereira, M., Sepúlveda, M., Siracusano, G., Cárcamo, J., Castellano, D., Gutiérrez, S., Tomasini, E., Corti, P. 2016 "Carlos Rúa, Programa iconográfico y material en las pinturas murales de la iglesia de san Andrés de Pachama, Chile". Colonial Latin American Review Vol. 25, № 2, pp. 245-264.

Hidalgo, J., Castro, N. y González, S.

2004 "La Revisita de Codpa (Altos de Arica) de 1772-73 efectuada por el corregidor Demetrio Egan". Chungara, 36:103-204.

Latasa, P.

2012 Escenificación del poder episcopal en Charcas: fiestas en la entrada del arzobispo Borja (1636). En Mundos trasatlánticos: trabajos y diversiones. Monográfico de literatura colonial, coordinado y editado por M. Donoso Rodríguez. Taller de Letras, GRISO, Pontifica Universidad Católica de Chile.

Luque Alcaide, E.

2001 "El primer ciclo evangelizador hispano y lusoamericano (siglo XVI)". En Dos mil años de evangelización. los grandes ciclos evangelizadores, coordinado por E. de la Lama, M. Merino y M. Lluch, pp. 259-274. Servicio de Publicaciones de la Universidad de Navarra, Pamplona.

Marsilli, M. y Cisternas, P.

2010 "Los senderos de la idolatría. El viaje de Vázquez de Espinosa por los Altos de Arica, 1618”. Chungara, 2:465-476.

Martínez, J. L., Diáz, C., Tocornal, C., Acuña, G. y Narbona, L. M.

2016 "Qeros y discursos visuales en la construcción de la nueva sociedad colonial andina". Anuario de Estudios Americanos, 73:15-43.

Molinié, A.

2003 "Metamorfosis andinas del toro". Revista de Estudios Taurinos, 16:19-34.

Ortega, M.

2016 "Andean Metaphysical concepts and the role of imagery in Catholic religious instruction". Diálogo Andino No 50 pp. 167-180.

Panofsky, E.

1985 El significado en las artes visuales. Alianza, Madrid.

Pereira Salas, E.

1947 Juegos y alegrías coloniales en Chile. Zig-Zag, Santiago.

Salcedo, J.

2007 Los jeroglíficos incas: Introducción a un método para descifrar tocapus-quillca. Estudio del Quero 7511 conservado en el Museo de América de Madrid. Universidad Nacional de Colombia, Bogotá.

Siracusano, G.

2010 "Notas para detener el escándalo: fiesta, color e idolatría en el virreinato del Perú”. En La Paleta del Espanto. Color y Cultura en los Cielos e Infiernos de la Pintura Colonial, editado por G. Siracusano, pp. 87-111. Colección Artes y Letras, UNSAM, Buenos Aires.

Tomoeda, $\mathrm{H}$.

2013 El toro y el cóndor, Fondo Editorial del Congreso del Perú, Lima.

Vargas Ugarte, R.

1952 Concilios Limenses (1551-1772). Tomo I. Arzobispado de Lima, Lima.

Villaroel, F. G. de.

1783 Gobierno eclesiástico-pacífico y unión de los dos cuchillos pontificio y regio. Madrid, Antonio Marín. 


\section{Notas}

1 Los historiadores del arte Flores Ochoa, Kuon y Samanez afirman que la pintura mural del siglo XVIII dejó de ser evangelizadora, comulgando del espíritu secularizador que comienza a reinar entonces (Flores Ochoa et al. 1991). Como veremos en este artículo, no compartimos este postulado respecto de la pintura mural costumbrista de la iglesia de Pachama.

2 Para mediados del siglo XVIII, el pueblo de Pachama tenía, aproximadamente, 150 habitantes. A estos podrían sumárseles los habitantes de Belén, que está situado a pocos kilómetros de Pachama. Según los datos de la revisita a Codpa de Demetrio Egan de 1772, Belén habría tenido 469 habitantes (Hidalgo et al. 2004).

3 La doctrina de Belén fue fundada en 1777 cuando la doctrina de Codpa, al sur del virreinato del Perú, fue dividida por Manuel de Abad Ylana. La doctrina de Belén estaba compuesta por diez localidades: Belén, Socoroma, Putre, Pachama, Parinacota, Caquena, Guallatire, Choquelimpie, Sora y Churiña.

4 Archivo Arzobispal de Arequipa (en adelante AAA). Serie: Arica Subserie: Belén. Demarcación y lista de contribuyentes de diezmos (impuesto de $10 \%$ de la producción agrícola para la iglesia). Fecha: 10/ 07/ 1787 foja 2r.

5 Para una completa y desarrollada información sobre Vázquez de Espinosa y su obra, véase Marsilli, M. y Cisternas P. (2010).

$6 \quad$ Pareciera que los mentores de esta pintura mural fueron los religiosos, especialmente los doctrineros de la zona (Gisbert 1998).

7 Según Teresa Gisbert las superficies cubiertas de pintura son tan grandes que sus autores solo pueden haber sido indígenas, ya que no era posible pagar tanta mano de obra (Gisbert 1992:18).

8 "Carta circular del sor obispado de Areqpa. Antes de ayer he recibido un oficio del Sor Gobr. Intendente el que me acompaña la soberana orden de las cortes dirigidas es que en orden de todos los cadáveres de los que allesiere sean de la clase o estado que fuesen se entierren en el campo santo, y de ninguna manera en los templos como se ve claramente en los documentos" p. 42. Archivo Nacional; Fondo parroquial de Belén, Vol. 5, Microficha 7.

$9 \quad$ En las paredes de la iglesia de Parinacota también hay una escena de confesión, lo que nos refuerza la idea misional de estas iglesias, en que el sacramento de la penitencia era fundamental como forma de redimirse de los pecados de idolatrías y de las malas costumbres.

10 En este sentido, Potosí es mucho más que una ciudad definida por su jurisdicción colonial, sino que está compuesta por las gentes, objetos, cartas, ideas que circulan desde y hacia la ciudad.
11 Para Jaime Salcedo, los tokapus son verdaderos jeroglíficos y consisten en una serie de rectángulos, en cada uno de ellos se inscribe un diseño particular. Salcedo introduce, asimismo, las definiciones históricas del término, aludiendo a las descripciones de fray Martín de Murúa, Pedro Cieza de León y Diego González de Holguín. Respecto de las interpretaciones contemporáneas, hay quienes piensan que son ideogramas que representan conceptos (Victoria de la Jara), otros que piensan que constituían una forma de escritura alfabética (William Burns Glynn) y otros que han propuesto sistemas mixtos de interpretación (Mario Sandron) o que la clave está en la forma y el color como agentes de significación (Cummins). (Salcedo 2007).

12 Los keros fueron los vasos rituales de madera utilizados para brindar en las ceremonias andinas. Se utilizaban principalmente en brindis de reciprocidad y en ceremonias asociadas al poder incaico. Durante el Tawantinsuyo formaron parte de los regalos de los inkas a los miembros de las élites de pueblos conquistados e incorporados al imperio cuzqueño. Se siguieron fabricando en período colonial. Para estudiar temas asociados a keros, véase Martínez et al. (2016).

13 A América llegaron muchos grabados flamencos para satisfacer una demanda local de imágenes y de noticias del Europa. Por lo demás, en América no había imprenta.

14 Las resonancias de Potosí también se aprecian en las influencias estilísticas de la portada de la iglesia de san Santiago de Belén. El estilo de la portada de la iglesia de Santiago, es también una fuente que nos habla de los intercambios y circulación de influencias en el Altiplano andino en épocas coloniales. Ciertos elementos iconográficos de la portada están presentes en iglesias potosinas, lo que es muestra de que Belén formaba parte de un circuito de circulación de personas y objetos de toda índole.

15 Bartolomé Arzáns de Orsúa y Vela (1676-1736) nació en Potosí. Poco se sabe de su vida personal excepto que era hijo de inmigrantes de Sevilla. Su obra más importante es la Historia de la Villa Imperial de Potosí, una historia épica de la ciudad. Su obra se refiere, principalmente, a las costumbres sociales. Esta obra permaneció inédita hasta el siglo XX.

16 AAA. Sección Vicaría, Serie Arica, Subserie Belén. Tipo de documento: Mayordía de las Cofradías de Belén. Fecha 21/01/1845-09/07/1846. "1845: Sobre que Francisco Cuellas sea Mayordomo de las Cofradías de Belén en lugar de Blas Benavides. N 66" Sin Foliar.

17 AAA. Sección Vicaría, Serie Arica, Subserie Belén. Tipo de documento: Mayordía de las Cofradías de Belén. Fecha 21/01/1845-09/07/1846. "1845: Sobre que Francisco Cuellas sea Mayordomo de las Cofradías de Belén en lugar de Blas Benavides. No 66" Sin Foliar. 